solitary symptom and premenstrual tension as a syndrome is suggested by the fact that in our study of the former significant reductions in TBW during the premenstruum occurred in only five out of 39 patients, only one of whom had a depressive personality trait, while Herzberg found a significant decrease premenstrually in 11 nuns with severe premenstrual tension. Possibly diuretics taken in the premenstruum might induce depression. ${ }^{8}$ In our study no single psychoneurotic trait or cluster of traits was characterised by either an increase or a decrease in total body water.

Conclusions-Although there may be some cases of cyclical mastalgia in which an increase in premenstrual water contributes to the symptom, the prescription of diuretics for most patients with this condition has no rational basis. The need for a simple means of recognising those, if any, likely to be helped by diuretics is apparent and other methods of treating the condition should be evaluated.

We are grateful to Mr M Baum and Mr P M Bolton for referring patients. We also thank the hospital staff who volunteered as controls, in particular Miss Joyce Wells, teaching department, Cardiff Maternity Hospital, who encouraged her colleagues to participate. Mr Mostyn Kearle constructed the computer program and $\mathrm{Mr}$ Robert Newcombe gave statistical advice. The work was done while one of us (PEP) was in receipt of a grant from the Medical Research Council.

\section{References}

1 Tonks, C M, British fournal of Hospital Medicine, 1968, 1, 383.

2 Dalton, K, The Premenstrual Syndrome, p 58. London, Heinemann, 1964.

${ }^{3}$ Israel, S L, Menstrual Disorders and Sterility, 5th edn, p 166. New York Harper and Row, 1967.

${ }^{4}$ Lamb, W M, et al, American fournal of Psychiatry, 1953, 109, 840.

${ }^{5}$ Klein, I, and Carey, J, American fournal of Obstetrics and Gynecology, $1957,74,956$.

${ }^{6}$ Bruce, J, and Russell, G F M, Lancet, 1962, 2, 267.

7 Russell, G F M, Fournal of Psychosomatic Research, 1972, 16, 279.

${ }^{8}$ Herzberg, B N, Fournal of Psychosomatic Research, 1971, 15, 251.

${ }^{9}$ International Commission on Radiological Protection, Protection of the Patient in Radionuclide Investigations, p 36. London, Pergamon Press, 1971

10 Haxhe, J J, Radioisotopes in Medical Diagnosis, ed E H Belcher and H Vetter, p 262. London, Butterworth, 1971.

${ }^{11}$ Silver, S, Radioactive Nuclides in Medicine and Biology, p 323. Philadelphia, Lea and Febiger, 1968.

12 Crown, S, and Crisp, A H, British fournal of Psychiatry, 1966, 112, 917.

13 Crown, S, Duncan, K P, and Howell, R W, British Fournal of Psychiatry, 1970, 116, 33.

14 Dransfield, G A, and Milne, H B, British fournal of Psychiatry, 1967, 113, 573.

15 Richards, A R, submitted for publication.

16 Hill, G L, et al, British fournal of Surgery, 1974, 61, 189.

17 Bailey, H, and Love, M, A Short Practice of Surgery, 12th edn, p 685. London, Lewis, 1962.

18 Ingleby, H, Bulletin of the International Association of Medical Museums, 1949, 29, 87.

19 Pellanda, E B, Revista de Medicina do Rio Grande do Sul, 1954, 10, 365.

\title{
Regulation of 3-hydroxy-3-methylglutaryl coenzyme-A reductase activity in type II hyperlipoproteinaemia
}

\author{
D J BETTERIDGE， M J P HIGGINS， D J GALTON
}

British Medical fournal, 1975, 4, 500-502

\section{Summary}

The regulation of 3-hydroxy-3-methylglutaryl coenzymeA reductase activity in leucocytes was studied in a family with familial type II hyperlipoproteinaemia (WHO classification). The propositus was heterozygous and 16 other members of the family were studied. Leucocytes were isolated by a relatively quick and simple procedure and used for enzyme estimations. The results suggest that measurement of the regulation of this enzyme in leucocytes may be helpful in the diagnosis and management of the condition.

\section{Introduction}

Familial type II hyperlipoproteinaemia (WHO classification), an inherited metabolic disorder, is characterised by the accumulation of low-density lipoproteins transporting cholesterol in the blood. Homozygous patients have raised cholesterol levels (over $13.0 \mathrm{mmol} / 1 ; 502 \mathrm{mg} / 100 \mathrm{ml}$ ), xanthomata and vascular disease appearing at an early age. Heterozygotes also have an increased incidence of premature vascular disease, which is quantitatively more important because of the frequency of the heterozygous state.

\footnotetext{
Lipid Research Laboratory, St Bartholomew's Hospital, London EC1A 7 BE

D J BETTERIDGE, BSC, MRCP, medical registrar

M J P HIGGINS, BSC, PHD, biochemist

D J GALTON, MD, MRCP, consultant physician
}

An important rate-determining step in cholesterol biosynthesis is catalysed by 3-hydroxy-3-methylglutaryl coenzyme-A reductase (EC 1.1.1.34; HMG CoA reductase). Although most studies have used rat and mouse liver systems, available evidence indicates that this is also true in man. Thus Williams and Avigan $^{1}$ reported the stimulation of acetate incorporation into cholesterol in human fibroblasts and leucocytes in culture when the medium contained delipidated instead of whole serum, and suggested that this was due to induction of HMG CoA reductase. Fogelman et al ${ }^{2}$ supported this hypothesis and suggested that the greater induction of HMG CoA reductase that they observed on transferring leucocytes from patients with heterozygous type II hyperlipoproteinaemia to medium containing a low lipid concentration was due to a defective sterol-binding "repressor" in the cell. Brown et al, ${ }^{3}{ }^{4}$ using fibroblasts from a homozygous patient, found defective inhibition of HMG CoA reductase activity in cells incubated with low-density lipoproteins and reported an intermediate pattern in heterozygotes. Their evidence suggested a defective binding of low-density lipoproteins to the cell membrane of fibroblasts in affected people.

We report the finding of defective regulation of HMG CoA reductase activity in leucocytes from a patient with familial heterozygous type II hyperlipoproteinaemia and present a study of this enzyme in the patient's family, showing the value of measuring the enzyme in identifying those affected.

\section{Materials and methods}

The propositus (subject II 7 ; see table) was investigated and treated as an inpatient. Members of his family were visited individually. Fasting venous blood samples were taken into tubes containing disodium edetate (final concentration $2 \mathrm{mmol} / \mathrm{l}$ ) for cholesterol and triglyceride measurement, lipoprotein electrophoresis, and the isola- 
tion of leucocytes for assay of HMG CoA reductase activity. Cholesterol values were determined by an automated fluorometric method based on the Liebermann-Burchardt reaction, and triglycerides by an automated fluorometric method using the Hantzch reaction. Lipoprotein electrophoresis was performed on Cellogel cellulose acetate strips.

Leucocytes were prepared by the method of Coulson and Chalmers. ${ }^{5}$ Blood treated with disodium edetate was mixed in siliconised vessels with two parts by volume of $3^{\circ}{ }_{1}$, gelatin in isotonic saline containing disodium edetate $(2 \mathrm{mmol} / \mathrm{l})$. The mixture was allowed to separate at $37 \mathrm{C}$ for $\mathbf{4 0}$ minutes, after which the supernatant was carefully withdrawn using a siliconised wide-bore pipette. After a single centrifugation $(1000 \mathrm{~g}$ for three minutes at room temperature) the cells were resuspended in deionised water $(37 \mathrm{C})$ and immediately recentrifuged at $1000 \mathrm{~g}$ for five minutes. The white pellet, suspended in KrebsRinger phosphate buffer $\mathrm{pH} 7.3$ containing $0.03 \mathrm{~mol}$ glucose $/ 1$, consisted of leucocytes microscopically indistinguishable from the cells in whole fresh blood. There was less than one reticulocyte $/ 500$ leucocytes. Leucocytes prepared in this way actively incorporated ${ }^{14} \mathrm{C}$-acetate into cholesterol (purified through the dibromide derivative), confirming the results of Fogelman $e t a l^{2}$ that the use of lipid-free serum results in a noticeable stimulation of incorporation.

HMG CoA reductase activity in leucocytes was assayed essentially as for fibroblasts. ${ }^{3}$ For economy a less sensitive method $^{6}$ was used when good yields of leucocytes were available with high enzyme activity. Unfortunately the method cannot be generally used because of high blank values, which are probably due to deacylase activity. ${ }^{2}$ Incubations for enzyme assays were terminated after 15 minutes, control experiments having shown the assay to be linear over 60 minutes. Cells were incubated in the medium containing $30 \%$ complete fetal calf serum (FCS) or $30^{\circ}{ }^{\circ}$ delipidated FCS. Apart from the use of FCS rather than human serum these incubations were as described by Fogelman et al. ${ }^{2}$

\section{CASE HISTORY}

The propositus, an unmarried man aged 35 years, had had swellings on the back of his hands since his late teens. There was nothing to sugges ischaemic heart disease (IHD) or peripheral vascular disease. Hypercholesterolaemia $(12.35 \mathrm{mmol} / \mathrm{l} ; 477 \mathrm{mg} / 100 \mathrm{ml})$ was noted at the age of 20 years when he was investigated because of premature vascular disease and high serum cholesterol levels in a brother. Treatment of the hypercholesterolaemia had included clofibrate and nicotinic acid intermittently and low cholestero diets for a short time, none of which had been effective. Examination showed pronounced arcus. There were tendon xanthomata over the back of the hands and on the achilles and patellar tendons but no planar xanthomata. The cardiovascular system was normal. A glucose tolerance test gave a normal result, the chest $x$-ray picture was normal, and ECG showed only minor intraventricular conduction defects. Fasting lipids on admission were: cholesterol $11.05 \mathrm{mmol} / 1(427 \mathrm{mg} / 100 \mathrm{ml})$, and triglycerides $1.12 \mathrm{mmol} / 1(99 \mathrm{mg} / 100$ $\mathrm{ml}$ ). Lipoprotein electrophoresis showed an increased $\beta$-lipoprotein band. On the basis of the electrophoretic strip, the serum cholesterol level, the presence of tendon xanthomata, and the family history, familial type II hyperlipoproteinaemia was diagnosed. With a type II diet, cholestyramine $16 \mathrm{~g} /$ day, and clofibrate $1.5 \mathrm{~g} /$ day the cholesterol level fell from 11.05 $\mathrm{mmol} / \mathrm{l}(427 \mathrm{mg} / 100 \mathrm{ml})$ to $7 \cdot 15 \mathrm{mmol} / \mathrm{l}(276 \mathrm{mg} / 100 \mathrm{ml})$ in one week.

\section{FAMILY HISTORY}

The mother (subject I 2; see fig) was presumed to have been the affected parent. The father (I 1) was alive and had a normal cholesterol level and ECG trace. The propositus was therefore probably heterozygous for the condition. Two brothers (II 1 and II 6) with tendon xanthomata had died of myocardial infarction (MI), and another brother had hypercholesterolaemia and IHD. A son (III 12) of an affected sibling was known to have had hypercholesterolaemia at the age of 20 but could not be traced. Further observations are given in the table.

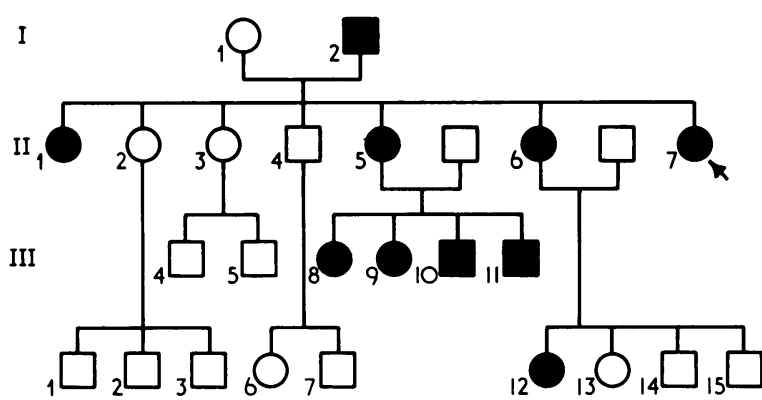

Family tree of propositus (arrowed). Affected female member.

\section{Results}

Fasting cholesterol and triglyceride levels together with HMG CoA reductase activity in leucocytes after incubation with complete or delipidated FCS are given in the table.

The propositus and one of his brothers (II 5) had raised fasting serum cholesterol levels, $(11.57 \mathrm{mmol} / 1(447 \mathrm{mg} / 100 \mathrm{ml})$ and 10.92 $\mathrm{mmol} / 1$ (422 $\mathrm{mg} / 100 \mathrm{ml})$ respectively), and lipoprotein electrophoresis showed a type IIa pattern. In neither case was HMG CoA reductase activity suppressed normally after incubation in complete FCS. The children of the brother of the propositus (III 8, 9, 10, and 11) also showed incomplete suppression of HMG CoA reductase activity. One of them (III 11) had a raised fasting serum cholesterol level, and in the others (III 8, 9, and 10) the levels were borderline. In the age group 1-19 years an upper limit of normal for cholesterol is 5.90 $\mathrm{mmol} / \mathrm{l}(228 \mathrm{mg} / 100 \mathrm{ml})$. The children's mother (see table) had a normal serum cholesterol level and a normally regulated enzyme. Two living brothers of the propositus (II 2 and II 3 ) had normal

Details of family studied together with plasma lipid levels and HMG CoA reductase activity in leucocytes

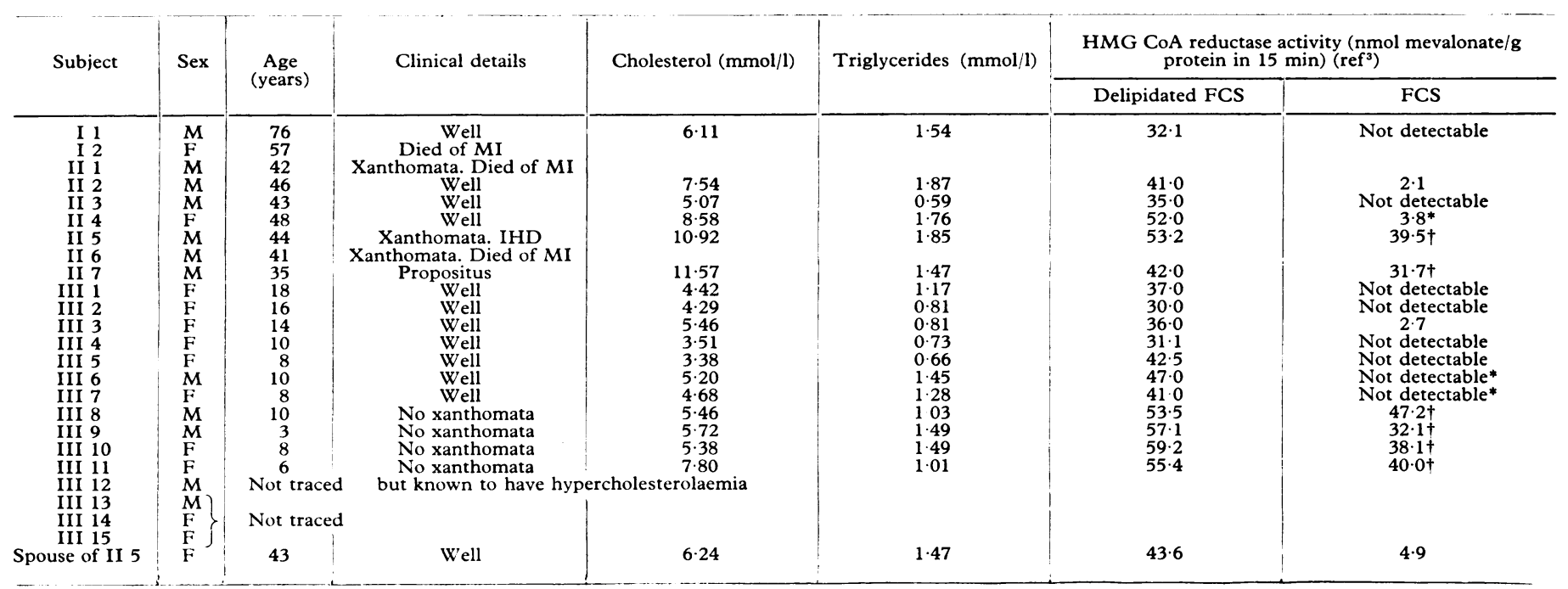


cholesterol values and normal regulation of HMG CoA reductase activity.

The sister of the propositus (II 4) and her children (III 6 and III 7) had cholesterol and triglyceride levels in the upper range of normal. Electrophoresis showed a type IIb pattern in these people, and studies on HMG CoA reductase activity showed normal suppression when incubated with complete FCS.

\section{Discussion}

HMG CoA reductase activity in cultured fibroblasts from patients with familial homozygous type II hyperlipoproteinaemia is not suppressed by low-density lipoproteins as it is in controls. ${ }^{3}$ In cultured fibroblasts from heterozygotes an intermediate pattern of control with partial lack of suppression has been observed. ${ }^{4}$ We report similar findings in leucocytes from heterozygotes. The study of this enzyme using leucocytes as a source, however, is a relatively fast and simple procedure when compared with the use of cultured fibroblasts and should therefore have greater clinical use.

The propositus and some of his relatives (II 5; III 8, 9, 10, and 11) had defective regulation of HMG CoA reductase. Some (II 7 and 5; III 11) had raised fasting cholesterol levels, and cholesterol levels in the others (III 8, 9, and 10) were at the upper range of normal. Other members of the family (II 4; III 3, 6, and 7) also showed borderline fasting serum cholesterol concentrations but their leucocyte HMG CoA reductase activity was normally regulated. These findings suggest that the measurement of this enzyme may be helpful in distinguishing familial heterozygous type II hyperlipoproteinaemia from other causes of hypercholesterolaemia.
More experience with enzyme assays in leucocytes is needed, however, before such observations can be accepted as an adequate diagnostic criterion for familial type II hyperlipoproteinaemia. This distinction may be important in the management of these patients. In patients with hypercholesterolaemia and normally regulated HMG CoA reductase activity low-cholesterol diets may prove to be disadvantageous by removing the normal inhibitory effect on the hepatic enzyme. This could result in increased synthesis of endogenous cholesterol. In familial type II hyperlipoproteinaemia a low-cholesterol diet may be beneficial, since the enzyme is always activated. Inhibition of HMG CoA reductase activity by drugs might prove to be more practicable in patients. with an abnormally regulated enzyme. Further work is in progress to assess this.

Our thanks are due to Professor $J$ Landon for help and advice and to Christine Gilbert for lipid analyses. This work was supported by a grant from the joint research board of St Bartholomew's Hospital.

Requests for reprints should be sent to Dr D J Galton.

\section{References}

1 Williams, C D, and Avigan, J, Biochimica et Biophysica Acta, 1972, 260, 413.

${ }^{2}$ Fogelman, M A, et al, fournal of Biological Chemistry, 1975, 250, 2045.

3 Brown, M S, and Goldstein, J L, Proceedings of the National Academy of Sciences, 1974, 71, 788.

${ }^{4}$ Goldstein, J L, and Brown, M S, Proceedings of the National Academy of Sciences, 1973, 70, 2804.

5 Coulson, A S, and Chalmers, D G, Lancet, 1969, 1, 468.

${ }^{6}$ Hulcher, F H, and Olsen, W H, fournal of Lipid Research, 1973, 14, 625.

\section{SHORT REPORTS}

\section{Endoscopic removal of a duodenal foreign body}

Ingested foreign bodies which impact beyond the cardio-oesophageal junction are beyond the reach of conventional oesophagoscopes and usually require surgical removal although some success is claimed using magnetic devices. ${ }^{12}$ Fibre-optic endoscopes bring the stomach and duodenum within reach so that foreign bodies can be removed from these sites without resorting to laparotomy.

\section{Case report}

$A B$, a 62-year-old edentulous bachelor, sneezed with an open safety pin between his lips. The pin was drawn into the pharynx and he accidentally swallowed it. He went to hospital three days later complaining of intermittent epigastric pain having vomited a small amount of altered blood. $X$-ray films showed the pin in the abdomen to the right of the upper lumbar spine (see figure).

In 1968 he had had a right nephrectomy for adenocarcinoma, which was followed by radiotherapy. This led to a colonic stricture, for which he had a right hemicolectomy in 1970. After this operation he developed a subphrenic abscess, but left hospital before it was drained. In 1974 he required the support of an implanted cardiac pacemaker.

Abdominal $x$-ray films showed no movement of the pin during the following week. In view of the patient's poor general condition and the likelihood of a difficult duodenal exposure, an attempt was made to remove the pin using a fibreoptic gastroscope. Under light sedation with diazepam an end-viewing instrument (Olympus GIF-D) was passed and the loop of the pin identified in the distal first part of the duodenum. The pin was surrounded by considerable oedema. Attempts to remove it failed because the grasping forceps would not work when the tip of the endoscope was considerably flexed in the duodenum.

A side-viewing instrument (Olympus GFB 2) gave a better view of the pin but again it was difficult to use the grasping forceps; so closed biopsy forceps were passed through the loop of the pin and opened. Fortunately, the pin was held by this manoeuvre and removed by withdrawing the instrument with the biopsy forceps in place. The patient remained fasting until chest and abdominal $x$-ray films six hours later failed to show any evidence of perforation of the duodenum, stomach, or oesophagus. Twentyfour hours later he was eating a normal diet.

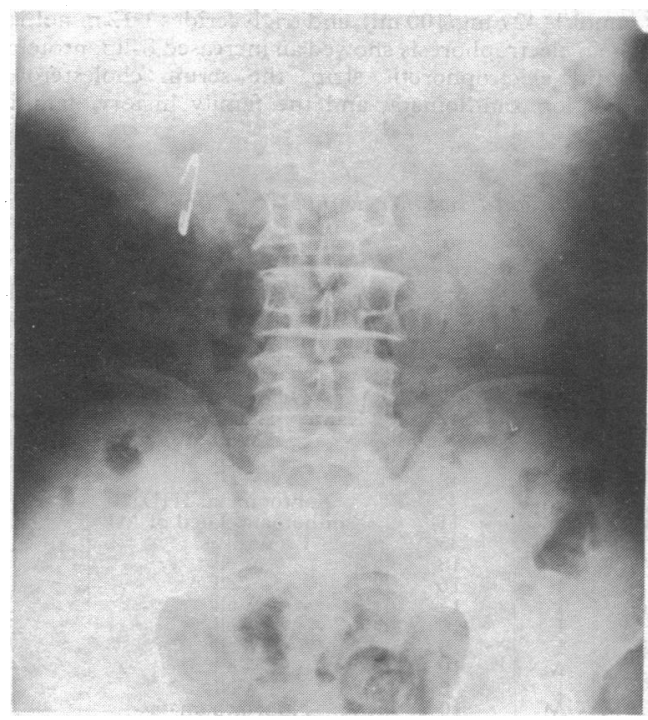

$X$-ray film showing the pin in the abdomen to the right of the upper lumbar spine.

\section{Discussion}

Although the majority of ingested foreign bodies will pass through the gut without major complications, ${ }^{3}$ in this case onward movement 